\title{
Stress-Related Herpesvirus Reactivation in Badgers Can Result in Clostridium Proliferation
}

\author{
Ming-shan Tsai@ ${ }^{1}$ Chris Newman, ${ }^{1,2}$ David W. Macdonald, ${ }^{1}$ and Christina D. Buesching ${ }^{1,2,3}$ \\ ${ }^{1}$ Wildlife Conservation Research Unit, Department of Zoology, University of Oxford, Recanati-Kaplan Centre, Abingdon Road, Tubney House, Tubney, \\ Oxfordshire OX13 5QL, UK \\ ${ }^{2}$ Cook's Lake Farming Forestry and Wildlife Inc (Ecological Consultancy), Queens County, NS, Canada \\ ${ }^{3}$ Department of Biology, Irving K. Barber Faculty of Science, The University of British Columbia, Okanagan, Kelowna, BC, Canada
}

\begin{abstract}
Clostridium perfringens is an important food-borne zoonotic pathogen and a member of the commensal gut microbiome of many mammals. Predisposing factors such as coinfection with other pathogens or diet change can, however, cause overgrowth and subsequent disease development. Here we investigated the occurrence of $C$. perfringens in a free-ranging badger population with up to $100 \%$ prevalence of herpesvirus infection. Herpesvirus reactivation is known to be associated with increased susceptibility bacterial infections. PCR screening of rectal swabs from 69 free-ranging badgers revealed 15.9\% $(11 / 69,95 \%$ CI $=9.1-26.3 \%)$ prevalence of detectable $C$. perfringens (Type A) DNA in the digestive tracts of assymptomatic animals. The results of Fisher's exact test revealed $C$. perfringens detection was not biased by age, sex and seasons. However, badgers with genital tract gammaherpesvirus (MusGHV-1) reactivation $(p=0.007)$ and infection with a specific MusGHV-1 genotype $(p=0.019)$ were more prone to of $C$. perfringens proliferation, indicating coinfection biased dynamics of intestinal $C$. perfringens. An inclusion pattern analysis further indicated that, causally, MusGHV-1 reactivation potentiated C. perfringens detection. Whether or not specific MusGHV-1 genotype infection or reactivation plays a role in C. perfringens overgrowth or disease development in badgers will require further investigation. Nevertheless, a postmortem examination of a single badger that died of fatal disease, likely associated with C. perfringens, revealed MusGHV-1 detection in the small intestine.
\end{abstract}

Keywords: gammaherpesvirus, sexually transmitted infection, wildlife, carnivora, one health, food-borne disease

\section{INTRODUCTION}

Supplementary Information: The online version contains supplementary material available at https://doi.org/10.1007/s10393-021-01568-2.

Published online: December 6, 2021

Correspondence to: Ming-shan Tsai, e-mail: cindy150051@gmail.com
Most vertebrates test positive for one or several herpesvirus species (Shrawat et al. 2018) because the host immune system is unable to eradicate the virus from the body after primary infection. Instead, herpesviruses undergo a period of latency inside host cells but can reactivate when the host immune system is weakened (e.g., due to stress: (Seeber 
et al. 2018; Baumworcel et al. 2019) or coinfection with other pathogens: (Dai et al. 2020a)): For example, the two human gammaherpesvirus species, the Epstein-Barr virus (EBV, causing mononucleosis) and the Kaposi's sarcomaassociated herpesvirus (KSHV), establish latency in lymphocytes after primary infection (Liang et al. 2009; Barton et al. 2011; Young et al. 2016; Johnson and Tarakanova 2020) and shed infectious virions into the oral cavity or genital tract when reactivated. The Equine gammaherpesviruses 2 and 5 (EHV-2 and EHV-5) are associated with abortion in mares, although the causal relationship remains unclear (Galosi et al. 2005; Marenzoni et al. 2013). In wild carnivores, gammaherpesviruses also produce pervasive, lifelong infection (e.g., felids: (Lozano et al. 2015; Tateno et al. 2017), musteloids: (King et al. 2004; Nicolas de Francisco et al. 2020), and ursids: (Black et al. 2019)). Repetitive reactivation, or active virus replication and shedding, happens asymptomatically but can occasionally cause recrudescent symptoms. These include pruritic (mucocutaneous) lesions or ulcers in the skin or genitalia, as well as neoplasms (Abade dos Santos et al., 2020; Gagnon et al., 2011; Nicolas de Francisco et al., 2020; Tsai, et al., 2020; Tseng et al., 2013). Although infections generally remain sub-patent, clinically severe disease can occur when host immunity is compromised due to senescence, stress responses, coinfections or neoplastic disease conditions (Sehrawat et al. 2018). One such comorbidity factor is the proliferation of Clostridium perfringens, as reported in Asian elephant calves (Elephas maximus) diagnosed with fatal Elephant endotheliotropic herpesvirus (EEHV) infection (Boonsri et al. 2018), and dairy cows (Frazier et al. 2002) and other captive artiodactyls (Flach et al. 2002) with Bovine herpesvirus 4 (BHV-4) infection.

C. perfringens is a spore-forming gram-positive bacterium and a common member of mammals, birds and reptiles' commensal gut microbiome (Lyhs et al. 2013; Meng et al. 2017; Milton et al. 2017; Ramos et al. 2019; Razmyar et al. 2014). However, in some cases, it can result in pathogenic zoonotic infections (Weese and Staempfli 2000; Van Immerseel et al. 2004; Silva and Lobato 2015). Eating foods, particularly undercooked meat contaminated with $C$. perfringens, is a common source of food poisoning due to the bacterium's ability to tolerate extreme high and low temperatures ( $\mathrm{Li}$ and McClane 2006) and aerobic conditions (Briolat and Reysset 2002). If dysbiosis occurs and $C$. perfringens proliferates in the small intestine, watery diarrhea and gastroenteritis can develop into necrotic enteritis. It can also cause emphysematous cholecystitis in the gallbladder and fulminate gas gangrene (also known as clostridial myonecrosis, caused by $\alpha$-toxins) in humans and other animals (Miyahara et al. 2013; Kiu and Hall 2018). Symptoms of $C$. perfringens food poisoning may include nausea, vomiting, abdominal pain and fever. Symptoms usually develop within $8-12 \mathrm{~h}$ but can take up to $24 \mathrm{~h}$ from ingestion. In extremis, $C$. perfringens can prove fatal in domestic animals and wildlife (Silva and Lobato 2015), although in human food poisoning cases it usually selfresolves within $24 \mathrm{~h}$ (Kiu and Hall 2018). The major virulence factor of $C$. perfringens arises from the secretion of various enterotoxins, which are used to classify the strain as Type A, B, C, D, E, F and G (Kiu and Hall 2018). The key enterotoxin of type A strain, also called the $\alpha$-toxin, causes hemolysis of erythrocytes (Sakurai et al. 2004), cell death, necrosis (Navarro et al. 2018) and disintegration of tight junctions between epithelial cells in the gut (Morris et al. 2012). Infections will respond to various antibiotic treatments, where clindamycin, metronidazole, rifampin and tetracycline are more efficacious than penicillin.

C. perfringens has frequently been isolated from the feces of healthy wild animal species in captivity or the field. Severe patho-morbidity is rare, although mortality due to necrotic enteritis has been reported in captive wild mammals and birds, and-more rarely-also in the field (Asaoka et al. 2004; Butler et al. 2008; Silva and Lobato 2015; Gartrell et al. 2017). A 3-year study by Vierheilig et al. (2013) revealed higher prevalence and abundance of $C$. perfringens in the feces of Carnivora than of ruminant wildlife species; another study by Cox et al. (2005) reported similar findings. These results suggest diet plays an important role in the epidemiology of $C$. perfringens (Silva et al. 2014), and second, that carnivores (such as feral dogs, cats, fish-eating avian species, foxes or badgers), omnivores (wild boar or domestic chickens) or scavengers (vultures) (Meng et al. 2017) may be significant sources of environmental C. perfringens contamination. It is thus essential to monitor and identify risk factors associated with high prevalence/prolific shedding of $C$. perfringens in animal feces at the human-livestock-wildlife interface, in order to establish and track transmission routes, as well as contamination levels in food or water sources (Van Immerseel et al. 2004; Kiu and Hall 2018).

The Mustelid gammaherpesvirus 1 (MusGHV-1) was first reported in 2002 (Banks et al. 2002) and confirmed to have an almost $100 \%$ prevalence in wild badger populations (King et al. 2004; Sin et al. 2014). MusGHV-1 infection is typically asymptomatic but results in a high 
occurrence of viral shedding in the genital tract (Kent et al. 2017). Genital MusGHV-1 reactivation in adults is linked to stressors (Tsai et al. 2021) and associated with impaired female reproductive capacity (Tsai et al. 2020). Although gammaherpesvirus reactivation generally involves no or only mild disease, it has been identified in other species as a predisposing factor for secondary bacterial infection or cancer development (Nordengrahn et al. 1996).

As part of an ongoing investigation into the causes and consequences of MusGHV-1 reactivation in the European badger, Meles meles (hereafter 'badger') (Tsai et al. 2021), here we examined demographic traits, seasons and coinfection with different strains of MusGHV-1 to identify risk factors associated with intestinal $C$. perfringens proliferation. We also report the results of a badger necropsy, where C. perfringens was abundant in the ileum, in Supplementary file 1.

\section{Materials and Methods}

To assess the background prevalence of $C$. perfringens in the study population, we tested 69 rectal swabs collected from 50 badgers sampled in 3 seasons (spring, summer and autumn) in 2018 (for detailed trapping and sampling methods, please see Tsai et al., 2021). None of these sampled animals exhibited any clinical symptoms indicative of $C$. perfringens infection at the time of sampling. DNA from the swabs was extracted and purified based on the method described in Tsai et al (2020) and the Qiagen DNeasy Blood and Tissue Kit according to the manufacturer's instruction. Purified DNA samples were screened using C. perfringens toxin genes-specific multiplex PCR (Baums et al. 2004) (Table 1). We also used a MusGHV-1 specific PCR (King et al., 2004; Tsai et al., 2020) targeting the DNA polymerase gene to detect MusGHV-1 DNA from the same rectal and genital swab samples. Based on substitutions in the partial MusGHV-1 DNA polymerase gene, two different MusGHV-1 genotypes circulate in our study population (Tsai et al. 2021). We determined the MusGHV-1 genotype for each individual with Sanger sequencing results of successfully amplified PCR products from genital swab samples (Tsai et al. 2021).

We used Fisher's exact test to identify the association between $C$. perfringens present in rectal swabs with sampling seasons, demographic traits, including sex and age group (juvenile: $<2$ years old; young adults: $2 \leq x<5$ years old; old adults: $5 \leq x<8$ years old; very old adults: $\geq 8$ years old), MusGHV-1 present in rectal/genital swabs and MusGHV-1 genotypes. We further applied an inclusion pattern analysis to explore the causal relationship between detection of MusGHV-1 and C. perfringens. We used the output derived from the equation $\frac{(b-c)^{2}}{(b+c)}$, which applied values taken from the diagonal of the $b$ and $c$ quadrants of the $2 \times 2$ table in Figure 1a. This output was then compared with the critical $\chi^{2}$ value at $1^{\circ}$ of freedom with $p$-values of 0.05 and 0.001 . An output higher than these critical $\chi^{2}$ values indicated a significant imbalanced diagonal quadrant. This would evidence that detection of either pathogen was not equally dependent and that one caused a predisposition to infection with the other; that is, when $b$ is greater than $c$ (or when $c$ is greater than $b$ ), then infection of pathogen $x$ is highly likely to predispose infection with pathogen $y$ (or y is highly likely to predispose for x) (Cavali-Sforza and Bodmer 1972).

\section{Results}

From the C. perfringens toxin genes-specific multiplex PCR results, in apparently asymptomatic animals the prevalence of $C$. perfringens was $15.9 \%(11 / 69,95 \% \mathrm{CI}=9.1-26.3 \%)$, with all positive instances classified as type A.

We found no overall association between rectal swab MusGHV-1 and C. perfringens detection rate (Fisher's exact test: $p=1$ ), nor any effect of season, sex, or age (Table 2). However, we identified a strong positive correlation between genital MusGHV-1 detection and intestinal C. perfringens detection (Pearson's $r$ value $=0.31$, Fisher's exact test $p$-value $=0.019)$. We also identified an imbalance of observations in the opposite diagonal of the inclusion correlation matrix (Fig. 1 provides a $2 \times 2$ matrix of MusGHV-1 DNA detected in genital swabs $(x)$ and $C$. perfringens DNA detected in rectal swabs $(y)$, collected concurrently from the same individual, where $a=9$, $b=23, c=2, d=34$, Fig. 1b). This inclusion pattern analysis gave a $\chi^{2}$ of 17.64 , which was much larger than the critical $\chi^{2}$ value at $p>0.05$ (3.84, with1 degree of freedom) or at $p>0.001$ (10.83, with1 degree of freedom). This indicated that $C$. perfringens detection was a consequence of MusGHV-1 reactivation. Thus, when C. perfringens was detected in the gut, MusGHV-1 was almost always reactivated; but when MusGHV-1 was reactivated, C. perfringens was not always detectable. Consequently, 
Table 1. Primer list used in this study.

\begin{tabular}{|c|c|c|c|c|c|}
\hline Gene & Name & Primer $\left(5^{\prime}-3^{\prime}\right)$ & Concentration $(\mu \mathrm{M})$ & Length & References \\
\hline \multicolumn{6}{|c|}{ Clostridium perfringens multiplex PCR } \\
\hline \multirow[t]{2}{*}{ cpa } & CPA5L & AGTCTACGCTTGGGATGGAA & 0.2 & 900 & Baums et al. (2004) \\
\hline & CPA5R & TTTCCTGGGTTGTCCATTTC & 0.2 & & \\
\hline \multirow[t]{2}{*}{$\mathrm{cpb}$} & CPBL & TCCTTTCTTGAGGGAGGATAAA & 0.138 & 611 & \\
\hline & CPBR & TGAACCTCCTATTTTGTATCCCA & 0.138 & & \\
\hline \multirow[t]{2}{*}{ cpe } & CPEL & GGGGAACCCTCAGTAGTTTCA & 0.067 & 506 & \\
\hline & CPER & ACCAGCTGGATTTGAGTTTAATG & 0.067 & & \\
\hline \multirow[t]{2}{*}{ etx } & CPETXL & TGGGAACTTCGATACAAGCA & 0.046 & 396 & \\
\hline & CPETXR & TTAACTCATCTCССATAACTGCAC & 0.046 & & \\
\hline \multirow[t]{2}{*}{ iap } & CPIL & AAACGCATTAAAGCTCACACC & 0.083 & 293 & \\
\hline & CPIR & CTGCATAACCTGGAATGGCT & 0.083 & & \\
\hline \multirow[t]{2}{*}{ cpb2 } & CPB2L & CAAGCAATTGGGGGAGTTTA & 0.117 & 200 & \\
\hline & CPB2R & GCAGAATCAGGATTTTGACCA & 0.117 & & \\
\hline \multicolumn{6}{|c|}{ Clostridium perfringens other toxin gene } \\
\hline \multirow[t]{2}{*}{ NetB } & NetB-F & CTTCTAGTGATACCGCTTCAC & 0.6 & 738 & Rood et al. (2018) \\
\hline & NetB-R & CGTTATATTCACTTGTTGACGAAAG & 0.6 & & \\
\hline \multirow[t]{2}{*}{ NetE } & NetE-F & TAGAAAACGTTCAATTGTATGG & 0.2 & 601 & \\
\hline & NetE-R & AGAAAGCGCTGATACAGCTAATAAA & 0.2 & & \\
\hline \multirow[t]{2}{*}{ NetF } & NetF-F & AACAATATGTACAGGTATAACT & 0.2 & 862 & Gohari et al. (2015) \\
\hline & NetF-R & TTGATAGGTATAATATGGTTCT & 0.2 & & \\
\hline \multirow[t]{2}{*}{ NetG } & NetG-F & TTGTTCAGGATTAGTAGCATTA & 0.2 & 860 & \\
\hline & NetG-R & CATGAGTTGCATAAGTTGGTGT & 0.2 & & \\
\hline \multicolumn{6}{|c|}{ Clostridium difficile multiplex PCR } \\
\hline \multirow[t]{2}{*}{$\operatorname{tcd} \mathrm{A}$} & tcdA-F & GCATGATAAGGCAACTTCAGTGGTAa & 0.6 & 629 & Persson et al. (2008) \\
\hline & tcdA-R & AGTTCCTCCTGCTCCATCAAATG & 0.6 & & \\
\hline \multirow[t]{3}{*}{$\mathrm{tcdB}$} & tcdB-F & CCAAARTGGAGTGTTACAAACAGGTG & 0.4 & 410 & \\
\hline & tcdB-R1 & GCATTTCTCCATTCTCAGCAAAGTA & 0.2 & & \\
\hline & tcdB-R2 & GCATTTCTCCGTTTTCAGCAAAGTA & 0.2 & & \\
\hline \multirow[t]{3}{*}{$\operatorname{cdt} \mathrm{A}$} & cdtA-F1 & GGGAAGCACTATATTAAAGCAGAAGC & 0.05 & 221 & \\
\hline & cdtA-F2 & CTGGGTTAGGATTATTTACTGGACCA & 0.05 & & \\
\hline & $\operatorname{cdtA}-\mathrm{R}$ & GGGAAACATTATATTAAAGCAGAAGC & 0.1 & & \\
\hline \multirow[t]{2}{*}{$\operatorname{ctdB}$} & $\operatorname{ctdB}-\mathrm{F}$ & TTGACCCAAAGTTGATGTCTGATTG & 0.1 & 262 & \\
\hline & ctdB-R & CGGATCTCTTGCTTCAGTCTTTATAG & 0.1 & & \\
\hline \multirow[t]{2}{*}{$16 \mathrm{~S}$ rDNA } & PS13 & GGAGGCAGCAGTGGGGAATA & 0.05 & 1062 & \\
\hline & PS14 & TGACGGGCGGTGTGTACAAG & 0.05 & & \\
\hline
\end{tabular}

MusGHV-1 reactivation appeared to act as a predisposing factor for $C$. perfringens proliferation in badger intestines.

Upon testing for any correlation between $C$. perfringens detection with either genotype, we found that $C$. perfringens occurrence was significantly more likely with the MusGHV-1 novel genotype, with a prevalence of $41.2 \%$ (7/ $17)$, compared to only $9.1 \%(4 / 44)$ in badgers infected with the MusGHV-1 common genotype (Fisher's exact test: $p=0.007)$.

\section{Discussion}

Our study demonstrates that $C$. perfringens detection was highly correlated with MusGHV-1 reactivation in the badgers we sampled. Furthermore, co-occurrence with $C$. 
(a)

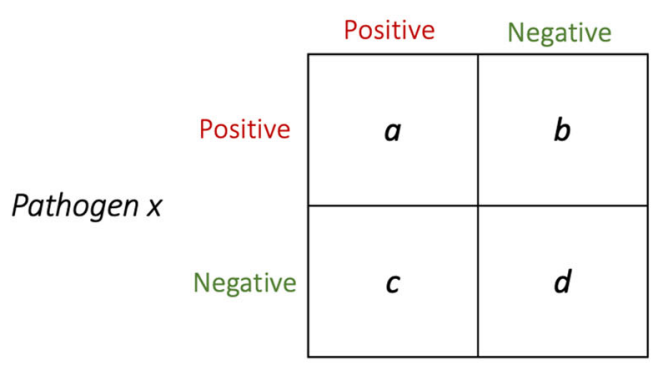

(b)

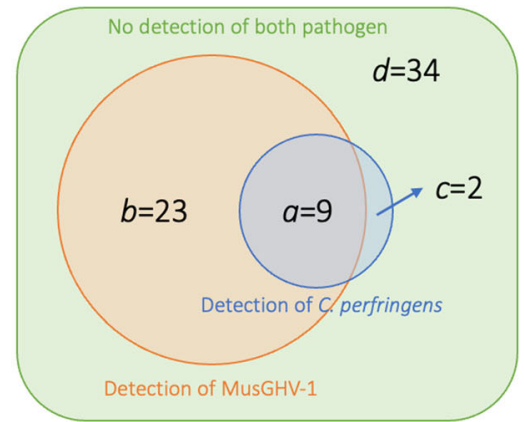

Figure 1. a A $2 \times 2$ table used for testing unequalness of observations ( $a=$ counts for individuals with positive detection of both pathogen $x$ and $y ; b=$ counts for individuals with positive detection of pathogen $x$ but negative for pathogen $y ; c=$ counts for individuals with negative detection of pathogen $x$ but positive detection of pathogen $y ; d=$ counts for individuals with negative detection of both pathogen $x$ and $y$ ). (Cavali-Sforza and Bodmer 1972). b Illustration of detection events of genital MusGHV-1 and C. perfringens of the sampled individuals ( $n=68$ ), where $C$. perfringens detection in gut is likely to be a consequence event of MusGHV-1 detection in genital tract.

Table 2. Univariate analysis of $C$. perfringens risk factors.

\begin{tabular}{|c|c|c|c|c|}
\hline Variable & C. p. Positive/total & Prevalence (\%) & $95 \%$ CI (\%) & $p$-value \\
\hline \multicolumn{5}{|l|}{ Season } \\
\hline Spring & $3 / 22$ & 13.6 & $4.7-33.3$ & \multirow[t]{3}{*}{0.097} \\
\hline Summer & $7 / 25$ & 28.0 & $14.2-47.6$ & \\
\hline Autumn & $1 / 22$ & 4.5 & $0.8-21.8$ & \\
\hline \multicolumn{5}{|l|}{$\operatorname{Sex}$} \\
\hline Male & $4 / 33$ & 12.1 & $4.8-27.3$ & \multirow[t]{2}{*}{0.337} \\
\hline Female & $7 / 36$ & 19.4 & $9.8-35$ & \\
\hline \multicolumn{5}{|l|}{ Age group } \\
\hline Juvenile & $5 / 23$ & 21.7 & $9.7-41.9$ & \multirow[t]{4}{*}{0.518} \\
\hline Young adult & $3 / 16$ & 18.8 & $6.6-43$ & \\
\hline Old adult & $0 / 8$ & 0.0 & $0-32.4$ & \\
\hline Very old adult & $3 / 22$ & 13.6 & $4.7-33.3$ & \\
\hline \multicolumn{5}{|c|}{ MusGHV-1 DNA in rectal swab } \\
\hline Positive & $7 / 36$ & 19.4 & $9.7-35$ & \multirow[t]{2}{*}{0.518} \\
\hline Negative & $4 / 33$ & 12.1 & $4.8-27.3$ & \\
\hline \multicolumn{5}{|c|}{ MusGHV-1 DNA in genital swab } \\
\hline Positive & $9 / 32$ & 28.1 & $15.6-45.4$ & \multirow[t]{2}{*}{0.019} \\
\hline Negative & $2 / 36$ & 5.6 & $1.5-18.1$ & \\
\hline \multicolumn{5}{|c|}{ MusGHV-1 genotype } \\
\hline Common & $4 / 44$ & 9.1 & $3.6-21.2$ & \multirow[t]{2}{*}{0.007} \\
\hline Novel & $7 / 17$ & 41.2 & $21.6-64$ & \\
\hline
\end{tabular}

perfringens was more likely to occur among individuals infected with the MusGHV-1 novel genotype. This shows that different individuals within the same population can have markedly different pathogen profiles and risks of disease pathogenesis. Although we did not investigate the directionality of causation empirically (whether the bacterium caused viral reactivation or viral reactivation com- promised immunity, allowing bacterial proliferation to detectable levels), the inclusion pattern we found (Fig. 1b) suggested that it is MusGHV-1 reactivation that promotes C. perfringens overgrowth.

From the postmortem results (Figs. 2, 3 and Supplementary file 1), we found that $C$. perfringens can proliferate in the badgers' ileum (Fig. 4). However, given the duration 

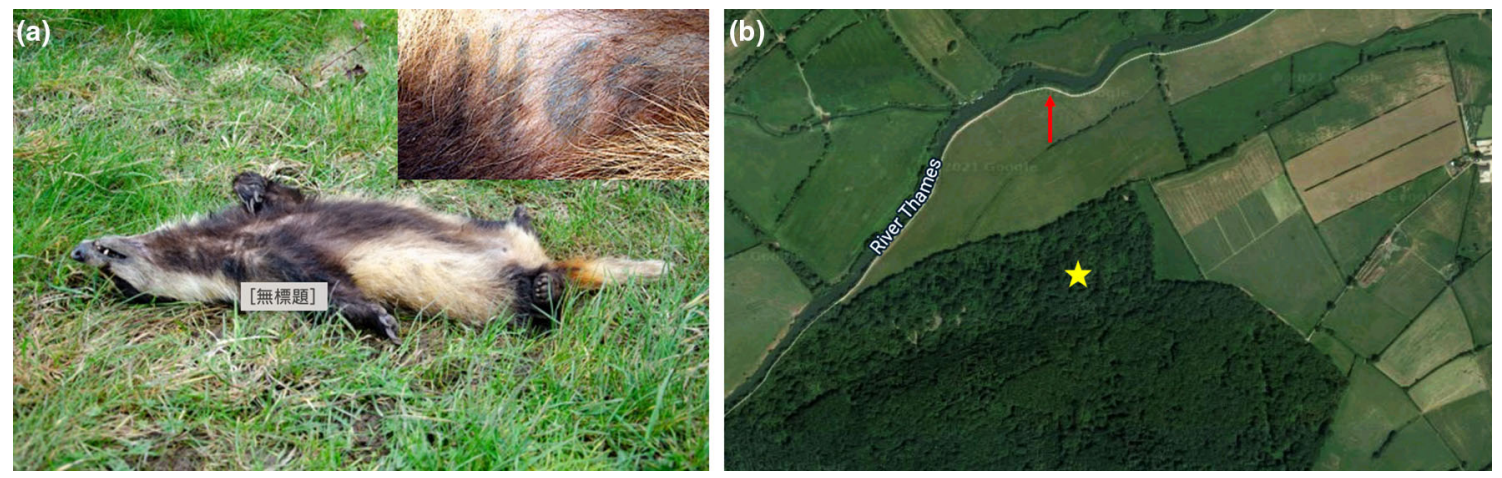

Figure 2. The female badger with tattoo number 1469 (a) found dead on a grassland near the River Thames (red arrow) about $770 \mathrm{~m}$ from her set of residency (yellow star) (b) (Color figure online).

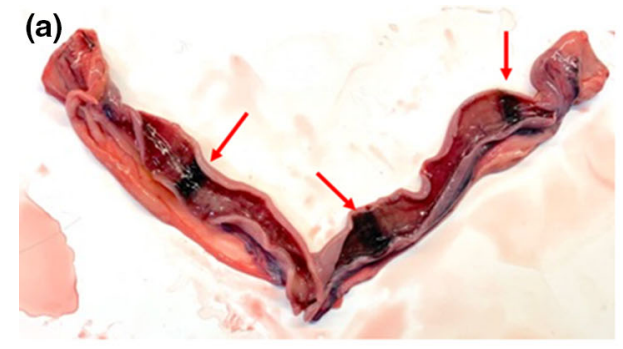

(c)
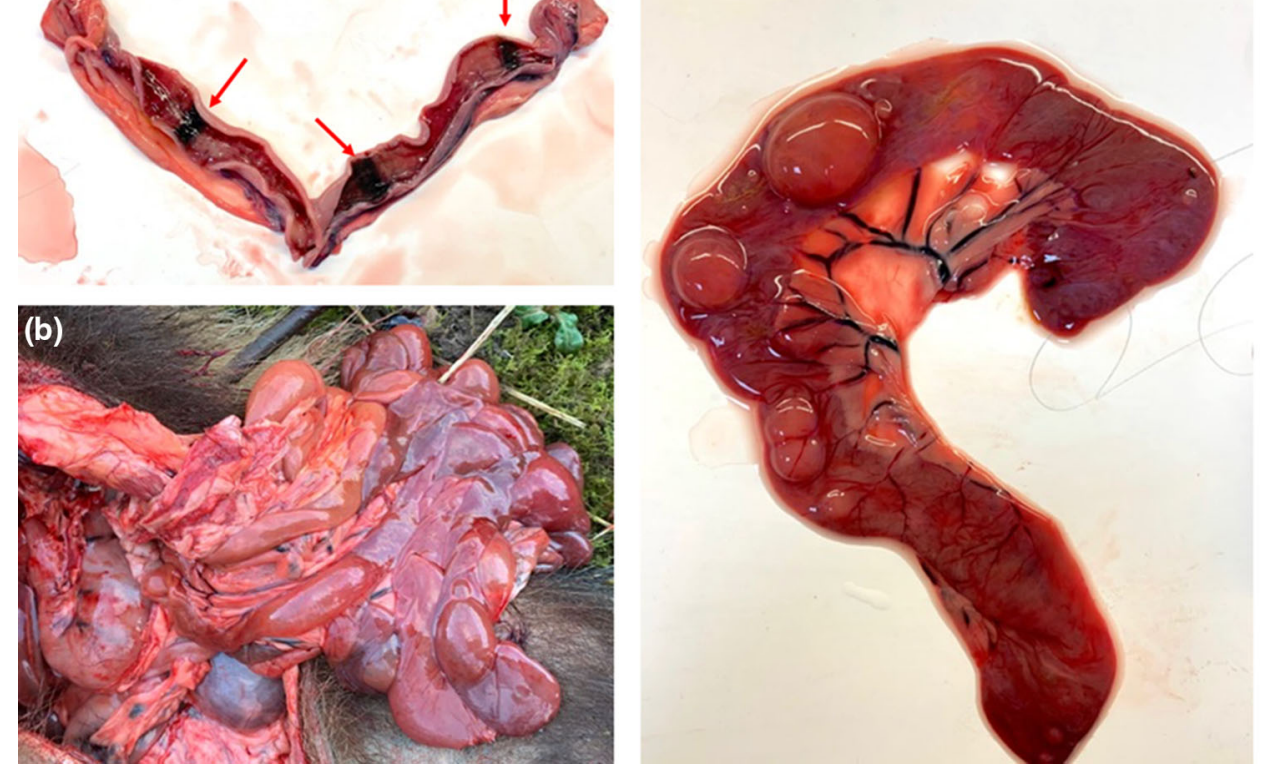

Figure 3. The fresh scars (red arrows) present in uterus of badger 1469 suggests that she had recently given birth to 3 cubs (a). The intestines of the badger were severely necrotic, enlarged and filled with gas (b). A closer look of the ileum (c) (Color figure online).
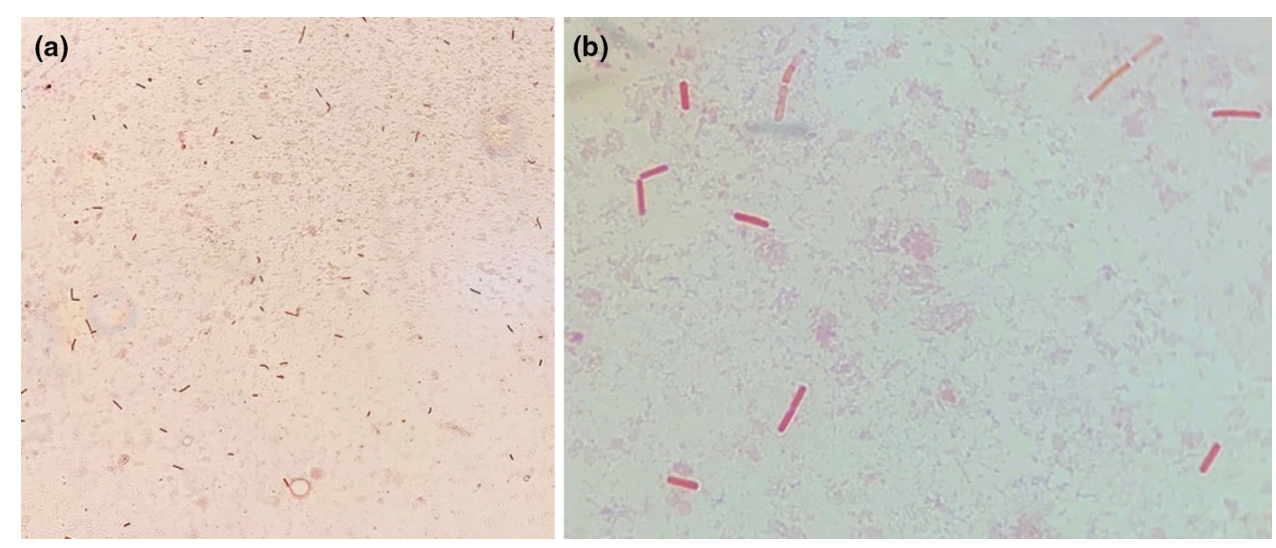

Figure 4. Gram stain revealed large amounts of rod-like gram-positive bacteria in the ileum mucous tentatively identified as $C$. perfringens under microscopic magnification of $40 \times(\mathbf{a})$ and $100 \times(\mathbf{b})$. 
over which the cadaver had been decomposing, it was impossible to determine whether necro-hemorrhagic enteritis was ante- or postmortem, and thus whether $C$. perfringens infection contributed to the cause of death of this individual, or whether this was solely autolysis leading to putrefaction (Fig. 5). Diagnosis of the pathophysiology arising from $C$. perfringens is very challenging because this pathogen is frequently present in the environment and often in the gut microbiome of healthy animals. Consequently, the differential elimination of competing pathogens from the diagnosis, combined with the application of multiple stands of symptomatic and clinical evidence, is required. Notably, however, at the final examination of this same individual in November 2019 (i.e., about 15 weeks before its death), as part of our long-term trapping and monitoring program (see Macdonald et al. 2015), the rectal swab we collected tested negative for $C$. perfringens. This suggests that the infection levels were either too low to be detected via conventional PCR or that the animal subsequently contracted this pathogen, perhaps fatally. However, the MusGHV-1 PCR sequencing product amplified from postmortem gut samples confirmed this individual carried the common genotype of MusGHV-1, which suggests that C. perfringens disease development may not be associated with the specific reactivated MusGHV-1 strain, despite being one of the risk factors for $C$. perfringens proliferation (Fig. 6).

Only one previous report has detected of $C$. perfringens infection in a European badger. The bacterium was isolated from the lung and spleen of a dead individual in Italy (Di Sabatino et al. 2016). The cause of death was diagnosed as canine distemper virus infection, with no discussion of any pathogenic role of C. perfringens (Di Sabatino et al. 2016). Pathologic infections with $C$. perfringens have been re- ported for other members of the Family Mustelidae, such as captive mink (Mustela (now Neogale) vison) (Macarie et al. 1980) and among captive breeding colonies of the highly endangered black-footed ferrets (Mustela nigripes) (Schulman et al. 1993). Wild Sea otters (Enhydra lutris nereis) are also susceptible to $C$. perfringens, where prevalence rates are 7.3 times higher among necropsied sea otters than livesampled individuals (Miller et al. 2010). In captivity, several Carnivora species have been reported suffering from disease or mortality associated with $C$. perfringens type A. These include a group of cheetahs (Acinonyx jubatus) infected with $C$. perfringens enterotoxin (cpe), which recovered after treatment (Citino 1995); 1 African lion (Panthera leo) and 1 Amur tiger (Panthera tigris altaica) with fatal consequences in a zoo (Zhang et al. 2012); and 2 Amur leopards (Panthera pardus orientalis) although no $C$. perfringens genotyping was done in this case to confirm the diagnosis (Neiffer 2001).

Ours is the first report of any link between MusGHV-1 and C. perfringens occurrence, although this co-stressor of immunity is similar to other examples of coinfections with C. perfringens and other pathogens that can damage intestinal mucosa. Examples include CPV in dogs (Silva et al. 2017), coccidia in chickens (Gallus gallus domesticus) (Collier et al. 2008), nematodes in Hamadryas baboons (Papio hamadryas) (Nikolaou et al. 2009) and turkeys (Meleagris gallopavo) (Norton et al. 1992). Compromised host immunity generally is a risk factor, as infection with $C$. perfringens diminishes mature neutrophils in bone marrow, leading to lowered replenishment of mature neutrophils in the peripheral circulation, resulting in an innate immune deficiency of the host (Takehara et al. 2016; Van Lieshout et al. 2020). Indeed, any stressful conditions causing an adrenocortical response (Herman et al. 2016), such as high-
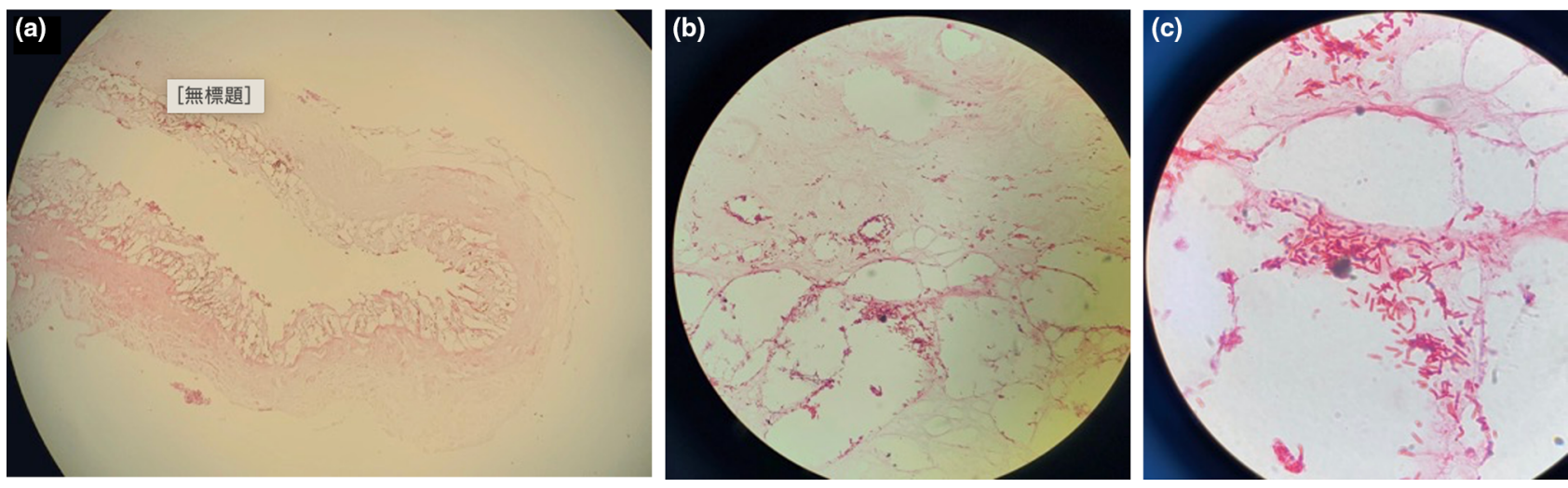

Figure 5. The histology pictures of the formalin-fixed ileum tissue at $4 \times(\mathbf{a})$ and gram-positive bacilli attached on lysed cells at $400 \times(\mathbf{b})$ and $1000 \times(\mathbf{a})$. 

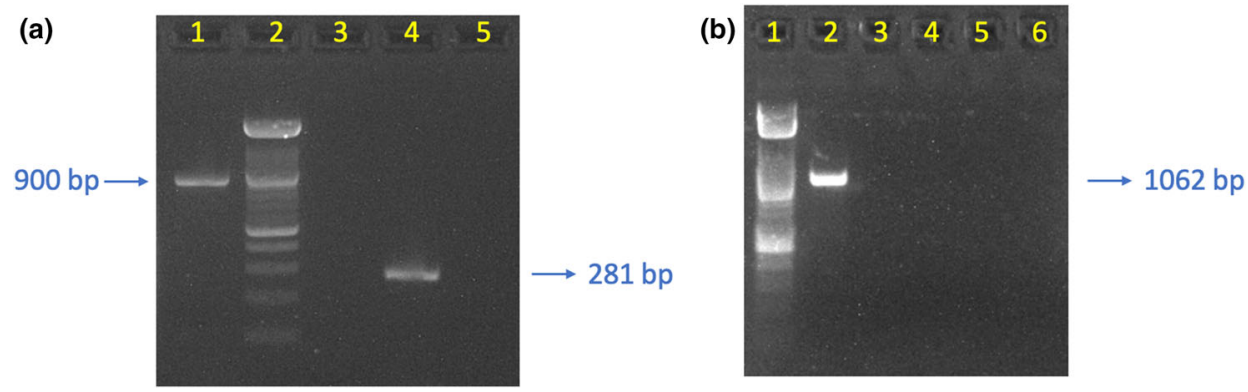

Figure 6. Gel images of the PCR amplification results of DNA extracted from $1469 \mathrm{~s}$ ileum tissue sample targeting various pathogen genes. a Lane1: multiplex PCR of $C$. perfringens toxins, only amplification of cpa gene is detected; lane 2: Ladders of DNA with 100 bp as interval; lane 3: amplification of canine circovirus rep gene; lane 4: amplification of MusGHV-1 DNA polymerase gene; lane 5: negative control with nucleasefree water as template. $\mathbf{b}$ Lane1: DNA ladder, lane 2: Multiplex PCR of C. difficile 16srDNA gene and toxin gene, only the C. difficile specific $16 \mathrm{~s}$ rDNA gene is detected; lane 3: amplification of $C$. perfringens $N e t B$ toxin gene; lane 4: amplification of C. perfringens $N e t E$ toxin gene; lane 5: amplification of $C$. perfringens $N e t F$ toxin gene; lane 6: amplification of $C$. perfringens $N e t G$ toxin gene.

density stocking in poultry (Tsiouris et al. 2015) and disruption of gut microbiome composition (Zaytsoff et al. 2020), pose potential risks. Other causes of $C$. perfringens enteritis include food poisoning (Grass et al., 2013) or the ingestion of feces infected with abundant $C$. perfringens cells, for example, from scavenging carcasses. In addition, a change to a high protein (Zentek et al. 2003) or high carbohydrate (Allison et al. 1975; Butler et al. 2008) diet can also predispose the gut to $C$. perfringens overgrowth.

Several studies report that gammaherpesvirus reactivation is associated with coinfection with other pathogens; for instance, EHV-2 was confirmed experimentally as a predisposing factor for Rhodococcus equi pneumonia in foals (Nordengrahn et al. 1996). Furthermore, more than $80 \%$ of infertile cows that tested positive for Bovine herpesvirus 4 also tested positive in pathogenic bacterial and/ or fungal culture results, including for $C$. perfringens as one of the primary species (Chastant-Maillard 2015). In humans, a series of studies examining KSHV revealed that the pathogen-associated molecular patterns (PAMPs) produced by Staphylococcus aureus can promote virus entry, latency establishment and reactivation in the oral cavity of HIV-positive patients (Dai et al. 2014, 2020b). In addition, several recent studies have applied high throughput sequencing to search for microbiome signals to indicate EBV and KSHV reactivation (Gruffaz et al. 2020; Urbaniak et al. 2020). Experimentally, Murid herpesvirus 4 primary infection has been established to sensitize mice to abortion induced by bacterial PAMPs, even at low doses (Cardenas et al. 2011). The above examples thus demonstrate that herpesvirus reactivation/viral shedding interacts closely with host microbiomes. Our results here imply a similar relationship between MusGHV-1 and C. perfringens in badgers, and stress-related MusGHV-1 reactivation may enhance shedding of this zoonotic bacterium into the environment. Generally, further investigation into disease causality and development is warranted to better understand the underlying mechanisms and consequences of infection. This will be informative for zoonotic disease management using the One Health approach in the interface between humans, domestic animals and wildlife.

\section{ACKNOWLEDGEMENTS}

The authors would like to thank Ewan Macdonald for reporting the badger carcass, which initiated the investigation of badger Clostridium perfringens in this free-ranging population

\section{Open Access}

This article is licensed under a Creative Commons Attribution 4.0 International License, which permits use, sharing, adaptation, distribution and reproduction in any medium or format, as long as you give appropriate credit to the original author(s) and the source, provide a link to the Creative Commons licence, and indicate if changes were made. The images or other third party material in this article are included in the article's Creative Commons licence, unless indicated otherwise in a credit line to the material. If material is not included in the article's Creative Commons licence and your intended use is not permitted by statutory regulation or exceeds the permitted use, you 
will need to obtain permission directly from the copyright holder. To view a copy of this licence, visit http://creativec ommons.org/licenses/by/4.0/.

\section{Data Availability}

All data generated or analyzed during this study are included in this published article as supplementary file 2 .

\section{REFERENCES}

Abade dos Santos FA, Monteiro M, Pinto A, Carvalho CL, Peleteiro MC, Carvalho P, Mendonça P, Carvalho T, Duarte MD (2020) First description of a herpesvirus infection in genus Lepus. BioRxiv Prepr . https://doi.org/10.1101/ 2020.01.21.913723

Allison MJ, Robinson IM, Dougherty RW, Bucklin JA (1975) Grain overload in cattle and sheep: changes in microbial populations in the cecum and rumen. Am J Vet Res 36:181-185

Asaoka Y, Yanai T, Hirayama H, Une Y, Saito E, Sakai H, Goryo M, Fukushi H, Masegi T (2004) Fatal necrotic enteritis associated with Clostridium perfringens in wild crows (Corvus macrorhynchos). Avian Pathol 33:19-24. https://doi.org/ 10.1080/03079450310001636228

Banks M, King DP, Daniells C, Stagg DA, Gavier-Widen D (2002) Partial characterization of a novel gammaherpesvirus isolated from a European badger (Meles meles). J Gen Virol 83:13251330. https://doi.org/10.1099/0022-1317-83-6-1325

Barton E, Mandal P, Speck SH (2011) Pathogenesis and host control of gammaherpesviruses: lessons from the mouse. Annu Rev Immunol 29:351-397. https://doi.org/10.1146/annurev-immunol-072710-081639

Baums CG, Schotte U, Amtsberg G, Goethe R (2004) Diagnostic multiplex PCR for toxin genotyping of Clostridium perfringens isolates. Vet Microbiol 100:11-16. https://doi.org/10.1016/ S0378-1135(03)00126-3

Baumworcel N, de Pereira JJ, Soares AMB, Souza GN, Almosny NRP, de Castro TX (2019) Feline herpesvirus 1 viral load related to environmental factors in sheltered cats. Ciência Rural 49:1-7. https://doi.org/10.1590/0103-8478cr20190067

Black W, Troyer RM, Coutu J, Wong K, Wolff P, Gilbert M, Yuan J, Wise AG, Wang S, Xu D, Kiupel M, Maes RK, Bildfell R, Jin L (2019) Identification of gammaherpesvirus infection in freeranging black bears (Ursus americanus). Virus Res 259:46-53. https://doi.org/10.1016/j.virusres.2018.10.016

Boonsri K, Somgird C, Noinafai P, Pringproa K, Janyamethakul T, Angkawanish T, Brown JL, Tankaew P, Srivorakul S, Thitaram C (2018) Elephant endotheliotropic herpesvirus associated with clostridium perfringens infection in two Asian elephant (Elephas maximus) calves. J Zoo Wildl Med 49:178-182. https:// doi.org/10.1638/2017-0001R1.1

Briolat V, Reysset G (2002) Identification of the Clostridium perfringens genes involved in the adaptive response to oxidative stress. J Bacteriol 184:2333-2343. https://doi.org/10.1128/ JB.184.9.2333-2343.2002

Butler EA, Jensen WF, Johnson RE, Scott JM (2008) Grain Overload and secondary effects as potential mortality factors of moose in North Dakota. Alces A J Devoted to Biol Manag Moose 44:73-79

Cardenas I, Mor G, Aldo P, Lang SM, Stabach P, Sharp A, Romero R, Mazaki-Tovi S, Gervasi MT, Means RE (2011) Placental Viral infection sensitizes to endotoxin-induced pre-term labor: a double hit hypothesis. Am J Reprod Immunol 65:110-117. https://doi.org/10.1111/j.1600-0897.2010.00908.x

Cavali-Sforza LL, Bodmer WF (1972) The genetics of human populations. In: Population (French Edition). p 910

Chastant-Maillard S (2015) Impact of bovine herpesvirus 4 (BoHV-4) on reproduction. Transbound Emerg Dis 62:245-251. https://doi.org/10.1111/tbed.12155

Citino S (1995) Chronic, intermittent Clostridium perfringens enterotoxicosis in a group of cheetahs (Acinonyx jubatus jubatus). J Zoo Wildl Med 26:279-285

Collier CT, Hofacre CL, Payne AM, Anderson DB, Kaiser P, Mackie RI, Gaskins HR (2008) Coccidia-induced mucogenesis promotes the onset of necrotic enteritis by supporting Clostridium perfringens growth. Vet Immunol Immunopathol 122:104-115. https://doi.org/10.1016/j.vetimm.2007.10.014

Cox P, Griffith M, Angles M, Deere D, Ferguson C (2005) Concentrations of pathogens and indicators in animal feces in the Sydney watershed. Appl Environ Microbiol 71:5929-5934. https://doi.org/10.1128/AEM.71.10.5929-5934.2005

Dai L, Barrett L, Plaisance-Bonstaff K, Post SR, Qin Z (2020) Porphyromonas gingivalis coinfects with KSHV in oral cavities of HIV+ patients and induces viral lytic reactivation. $J$ Med Virol . https://doi.org/10.1002/jmv.26028

Dai L, DeFee MR, Cao Y, Wen J, Wen X, Noverr MC, Qin Z (2014) Lipoteichoic acid (LTA) and lipopolysaccharides (LPS) from periodontal pathogenic bacteria facilitate oncogenic herpesvirus infection within primary oral cells. PLoS One 9:1-11. https://doi.org/10.1371/journal.pone.0101326

Dai L, Qiao J, Yin J, Goldstein A, Lin HY, Post SR, Qin Z (2020) Kaposi sarcoma-associated herpesvirus and staphylococcus aureus coinfection in oral cavities of HIV-positive patients: a unique niche for oncogenic virus lytic reactivation. J Infect Dis 221:1331-1341. https://doi.org/10.1093/infdis/jiz249

Di Sabatino D, Di Francesco G, Zaccaria G, Malatesta D, Brugnola L, Marcacci M, Portanti O, De Massis F, Savini G, Teodori L, Ruggieri E, Mangone I, Badagliacca P, Lorusso A (2016) Lethal distemper in badgers (Meles meles) following epidemic in dogs and wolves. Infect Genet Evol 46:130-137. https://doi.org/ 10.1016/j.meegid.2016.10.020

Flach EJ, Reid H, Pow I, Klemt A (2002) Gamma herpesvirus carrier status of captive artiodactyls. Res Vet Sci 73:93-99. https://doi.org/10.1016/S0034-5288(02)00094-2

Frazier KS, Baldwin CA, Pence M, West J, Bernard J, Liggett A, Miller D, Hines ME (2002) Seroprevalence and comparison of isolates of endometriotropic Bovine Herpesvirus-4. J Vet Diagnostic Investig 14:457-462. https://doi.org/10.1177/ 104063870201400602

Gagnon CA, Tremblay J, Larochelle D, Music N, Tremblay D (2011) Identification of a novel herpesvirus associated with cutaneous ulcers in a fisher (Martes pennanti). J Vet Diagn Investig 23:986-990. https://doi.org/10.1177/1040638711418615

Galosi CM, De La Paz VC, Fernández LC, Martinez JP, Craig MI, Barrandeguy M, Etcheverrigaray ME (2005) Isolation of equine herpesvirus-2 from the lung of an aborted fetus. J Vet Diagn Investig 17:500-502. https://doi.org/10.1177/ 104063870501700520 
Gartrell B, Agnew D, Alley M, Carpenter T, Ha HJ, Howe L, Hunter S, McInnes K, Munday R, Roe W, Young M (2017) Investigation of a mortality cluster in wild adult yellow-eyed penguins (Megadyptes antipodes) at Otago Peninsula, New Zealand. Avian Pathol 46:278-288. https://doi.org/10.1080/ 03079457.2016.1264568

Gohari IM, Parreira VR, Nowell VJ, Nicholson VM, Oliphant K, Prescott JF (2015) A novel pore-forming toxin in type A Clostridium perfringens is associated with both fatal canine hemorrhagic gastroenteritis and fatal foal necrotizing enterocolitis. PLoS One 10:1-27. https://doi.org/10.1371/journal.pone. 0122684

Grass JE, Gould LH, Mahon BE (2013) Epidemiology of foodborne disease outbreaks caused by clostridium perfringens, United States, 1998-2010. Foodborne Pathog Dis 10:131-136. https://doi.org/10.1089/fpd.2012.1316

Gruffaz M, Zhang T, Marshall V, Gonçalves P, Ramaswami R, Labo N, Whitby D, Uldrick TS, Yarchoan R, Huang Y, Gao SJ (2020) Signatures of oral microbiome in HIV-infected individuals with oral Kaposi's sarcoma and cell-associated KSHV DNA. PLoS Pathog 16:1-18. https://doi.org/10.1371/journal.ppat. 1008114

Herman JP, McKlveen JM, Ghosal S, Kopp B, Wulsin A, Makinson R, Scheimann J, Myers B (2016) Regulation of the hypothalamic-pituitary- adrenocortical stress response. Compr Physiol 6:603-621. https://doi.org/10.1002/cphy.c150015

Johnson KE, Tarakanova VL (2020) Gammaherpesviruses and B Cells: a relationship that lasts a lifetime. Viral Immunol 00:1-11. https://doi.org/10.1089/vim.2019.0126

Kent A, Ehlers B, Mendum T, Newman C, Macdonald DW, Chambers M, Buesching CD (2017) Genital tract screening finds widespread infection with mustelid gammaherpesvirus 1 in the European badger (Meles meles). J Wildl Dis 12-274. https://doi. org/10.7589/2016-12-274

King DP, Mutukwa N, Lesellier S, Cheeseman C, Chambers MA, Banks M (2004) Detection of Mustelid Herpesvirus-1 Infected European badgers (Meles meles) in the British Isles. J Wildl Dis 40:99-102. https://doi.org/10.7589/0090-3558-40.1.99

Kiu R, Hall LJ (2018) An update on the human and animal enteric pathogen Clostridium perfringens. Emerg Microbes Infect . https://doi.org/10.1038/s41426-018-0144-8

Li J, McClane BA (2006) Further comparison of temperature effects on growth and survival of Clostridium perfringens type A isolates carrying a chromosomal or plasmid-borne enterotoxin gene. Appl Environ Microbiol 72:4561-4568. https://doi.org/ 10.1128/AEM.00177-06

Liang X, Collins CM, Mendel JB, Iwakoshi NN, Speck SH (2009) Gammaherpesvirus-driven plasma cell differentiation regulates virus reactivation from latently infected B lymphocytes. PLoS Pathog . https://doi.org/10.1371/journal.ppat.1000677

Lozano CC, Sweanor LL, Wilson-Henjum G, Kays RW, Moreno R, VandeWoude S, Troyer RM (2015) Identification of novel gammaherpesviruses in ocelots (Leopardus pardalis) and Bobcats (Lynx rufus) in Panama and Colorado, USA. J Wildl Dis 51:911-915. https://doi.org/10.7589/2015-01-027

Lyhs U, Perko-Mäkelä P, Kallio H, Brockmann A, Heinikainen S, Tuuri H, Pedersen K (2013) Characterization of Clostridium perfringens isolates from healthy turkeys and from turkeys with necrotic enteritis. Poult Sci 92:1750-1757. https://doi.org/ 10.3382/ps.2012-02903

Macarie I, Cure C, Pop A, Institutul SB-LS, 1980 U (1980) Histopathology of natural Clostridium perfringens type A infection in mink. Lucr Stiint Institutul Agron Nicolae Balcescu 23:23-27

Macdonald DW, Newman C, Buesching CD (2015) Badgers in the rural landscape-conservation paragon or farmland pariah? Lessons from the Wytham Badger Project. Wildl Conserv Farml 2:65-95. https://doi.org/10.1093/acprof:oso/9780198745501.003 .0004

Marenzoni ML, Bietta A, Lepri E, Casagrande Proietti P, Cordioli P, Canelli E, Stefanetti V, Coletti M, Timoney PJ, Passamonti F (2013) Role of equine herpesviruses as co-infecting agents in cases of abortion, placental disease and neonatal foal mortality. Vet Res Commun 37:311-317. https://doi.org/10.1007/s11259013-9578-6

Meng X, Lu S, Yang J, Jin D, Wang X, Bai X, Wen Y, Wang Y, Niu L, Ye C, Rosselló-Móra R, Xu J (2017) Metataxonomics reveal vultures as a reservoir for Clostridium perfringens. Emerg Microbes Infect . https://doi.org/10.1038/emi.2016.137

Miller MA, Byrne BA, Jang SS, Dodd EM, Dorfmeier E, Harris MD, Ames J, Paradies D, Worcester K, Jessup DA, Miller WA (2010) Enteric bacterial pathogen detection in southern sea otters (Enhydra lutris nereis) is associated with coastal urbanization and freshwater runoff. Vet Res . https://doi.org/10.1051/ vetres/2009049

Milton AAP, Agarwal RK, Bhuvana Priya G, Saminathan M, Aravind M, Reddy A, Athira CK, Ramees T, Sharma AK, Kumar A (2017) Prevalence and molecular typing of Clostridium perfringens in captive wildlife in India. Anaerobe 44:55-57. https:// doi.org/10.1016/j.anaerobe.2017.01.011

Miyahara H, Shida D, Matsunaga H, Takahama Y, Miyamoto S (2013) Emphysematous cholecystitis with massive gas in the abdominal cavity. World J Gastroenterol 19:604-606. https:// doi.org/10.3748/wjg.v19.i4.604

Morris WE, Dunleavy MV, Diodati J, Berra G, Fernandez-Miyakawa ME (2012) Effects of Clostridium perfringens alpha and epsilon toxins in the bovine gut. Anaerobe 18:143-147. https:// doi.org/10.1016/j.anaerobe.2011.12.003

Navarro MA, McClane BA, Uzal FA (2018) Mechanisms of action and cell death associated with Clostridium perfringens toxins. Toxins (Basel) 10:1-21. https://doi.org/10.3390/toxins 10050212

Neiffer DL (2001) Clostridium perfringens enterotoxicosis in two Amur leopards (Panthera pardus orientalis). J Zoo Wildl Med 32:134-135. https://doi.org/10.1638/10427260(2001)032[0134:CPEITA]2.0.CO;2

Nicolas de Francisco O, Esperón F, Juan-Sallés C, Ewbank AC, Dis Neves CG, Marco A, Neves E, Anderson N, Sacristán C (2020) Neoplasms and novel gammaherpesviruses in critically endangered captive European minks (Mustela lutreola). Transbound Emerg Dis . https://doi.org/10.1111/tbed.13713

Nikolaou GN, Kik MJL, Van Asten AJAM, Gröne A (2009) B2toxin of clostridium perfringens in a hamadryas baboon (Papio hamadryas) with enteritis. J Zoo Wildl Med 40:806-808. https:// doi.org/10.1638/2009-0081.1

Nordengrahn A, Rusvai M, Merza M, Ekström J, Morein B, Belák S (1996) Equine herpesvirus type 2 (EHV-2) as a predisposing factor for Rhodococcus equi pneumonia in foals: Prevention of the bifactorial disease with EHV-2 immunostimulating complexes. Vet Microbiol 51:55-68. https://doi.org/10.1016/03781135(96)00032-6

Norton RA, Hopkins BA, Skeeles JK, Beasley JN, Kreeger JM (1992) High mortality of domestic turkeys associated with Ascaridia dissimilis. Avian Dis 36:469-473. https://doi.org/ $10.2307 / 1591532$ 
Persson S, Torpdahl M, Olsen KEP (2008) New multiplex PCR method for the detection of Clostridium difficile toxin. A (tcdA) and toxin. $\mathrm{B}(\mathrm{tcdB})$ and the binary toxin $(\mathrm{cdtA} / \mathrm{cdtB})$ genes applied to a Danish strain collection. Clin Microbiol Infect 14:1057-1064. https://doi.org/10.1111/j.1469-0691.2008.02092.x

Ramos CP, Santana JA, Morcatti Coura F, Xavier RGC, Leal CAG, Oliveira Junior CA, Heinemann MB, Lage AP, Lobato FCF, Silva ROS (2019) Identification and characterization of escherichia coli, salmonella spp., clostridium perfringens, and c. difficile isolates from reptiles in brazil. Biomed Res Int . https:// doi.org/10.1155/2019/9530732

Razmyar J, Kalidari GA, Tolooe A, Rad M, Movassaghi AR (2014) Genotyping of Clostridium perfringens isolated from healthy and diseased ostriches (Struthio camelus). Iran J Microbiol 6:3136

Rood JI, Adams V, Lacey J, Lyras D, McClane BA, Melville SB, Moore RJ, Popoff MR, Sarker MR, Songer JG, Uzal FA, Van Immerseel $F$ (2018) Expansion of the Clostridium perfringens toxin-based typing scheme. Anaerobe 53:5-10. https://doi.org/ 10.1016/j.anaerobe.2018.04.011

Sakurai J, Nagahama M, Oda M (2004) Clostridium perfringens alpha-toxin: characterization and mode of action. J Biochem 136:569-574. https://doi.org/10.1093/jb/mvh161

Schulman FY, Montali RJ, Hauer PJ (1993) Gastroenteritis associated with clostridium perfringens type A in black-footed ferrets (Mustela nigripes). Vet Pathol 30:308-310. https://doi.org/ $10.1177 / 030098589303000316$

Seeber PA, Quintard B, Sicks F, Dehnhard M, Greenwood AD, Franz M (2018) Environmental stressors may cause equine herpesvirus reactivation in captive Grévy's zebras (Equus grevyi). PeerJ . https://doi.org/10.7717/peerj.5422

Sehrawat S, Kumar D, Rouse BT (2018) Herpesviruses: Harmonious pathogens but relevant cofactors in other diseases? Front Cell Infect Microbiol 8:1-15. https://doi.org/10.3389/ fcimb.2018.00177

Silva ROS, Dorella FA, Figueiredo HCP, Costa ÉA, Pelicia V, Ribeiro BLD, Ribeiro MG, Paes AC, Megid J, Lobato FCF (2017) Clostridium perfringens and C. difficile in parvoviruspositive dogs. Anaerobe 48:66-69. https://doi.org/10.1016/ j.anaerobe.2017.07.001

Silva ROS, Ferreira Junior FC, Marques MVR, Oliveira Junior CA, da Martins NRS, Lobato FCF (2014) Genotyping and antimicrobial susceptibility of Clostridium perfringens isolated from Tinamidae, Cracidae and Ramphastidae species in Brazil. Ciência Rural 44:486-491. https://doi.org/10.1590/s010384782014000300016

Silva ROS, Lobato FCF (2015) Clostridium perfringens: a review of enteric diseases in dogs, cats and wild animals. Anaerobe 33:14-17. https://doi.org/10.1016/j.anaerobe.2015.01.006

Sin YW, Annavi G, Dugdale HL, Newman C, Burke T, MacDonald DW (2014) Pathogen burden, co-infection and major histocompatibility complex variability in the European badger (Meles meles). Mol Ecol 23:5072-5088. https://doi.org/ $10.1111 / \mathrm{mec} .12917$

Takehara M, Takagishi T, Seike S, Ohtani K, Kobayashi K, Miyamoto K, Shimizu T, Nagahama M (2016) Clostridium perfringens $\alpha$-Toxin Impairs Innate Immunity via Inhibition of Neutrophil differentiation. Sci Rep 6:1-10. https://doi.org/ 10.1038/srep28192

Tateno M, Takahashi M, Miyake E, Nishigaki K, Tsujimoto $\mathrm{H}$, Endo Y (2017) Molecular epidemiological study of gamma- herpesvirus in domestic cats in Japan. J Vet Med Sci 79:17351740. https://doi.org/10.1292/jvms.17-0039

Tsai M, Fogarty U, Byrne AW, O'Keeffe J, Newman C, Macdonald DW, Buesching CD (2020) Effects of Mustelid gammaherpesvirus 1 (MusGHV-1) reactivation in European badger (Meles meles) genital tracts on reproductive fitness. Pathogens 9:769. https://doi.org/10.3390/pathogens9090769

Tsai M, François S, Newman C, Macdonald DW, Buesching CD (2021) Patterns of Mustelid gammaherpesvirus 1 (MusGHV-1) genital reactivation linked to stressors in adult European badgers (Meles meles). In: Dryad

Tseng M, Fleetwood M, Reed A, Gill VA, Harris RK, Moeller RB, Lipscomb TP, Mazet JAK, Goldstein T (2013) Mustelid Herpesvirus-2, a novel herpes infection in Northern Sea Otters (Enhydra Lutris Kenyoni). J Wildl Dis 48:181-185. https:// doi.org/10.7589/0090-3558-48.1.181

Tsiouris V, Georgopoulou I, Batzios C, Pappaioannou N, Ducatelle R, Fortomaris P (2015) High stocking density as a predisposing factor for necrotic enteritis in broiler chicks. Avian Pathol 44:59-66. https://doi.org/10.1080/ 03079457.2014.1000820

Urbaniak C, Lorenzi H, Thissen J, Jaing C, Crucian B, Sams C, Pierson D, Venkateswaran K, Mehta S (2020) The influence of spaceflight on the astronaut salivary microbiome and the search for a microbiome biomarker for viral reactivation. Microbiome 8:56. https://doi.org/10.1186/s40168-020-00830-z

Van Immerseel F, De Buck J, Pasmans F, Huyghebaert G, Haesebrouck F, Ducatelle R (2004) Clostridium perfringens in poultry: an emerging threat for animal and public health. Avian Pathol 33:537-549. https://doi.org/10.1080/03079450400013162

Van Lieshout SHJ, Badás EP, Mason MWT, Newman C, Buesching CD, Macdonald DW, Dugdale HL (2020) Social effects on age-related and sex-specific immune cell profiles in a wild mammal: Immune cell profiles in a wild mammal. Biol Lett 16:0-6. https://doi.org/10.1098/rsbl.2020.0234rsbl20200234

Vierheilig J, Frick C, Mayer RE, Kirschner AKT, Reischer GH, Derx J, Mach RL, Sommer R, Farnleitner AH (2013) Clostridium perfringens is not suitable for the indication of fecal pollution from ruminant wildlife but is associated with excreta from nonherbivorous animals and human sewage. Appl Environ Microbiol 79:5089-5092. https://doi.org/10.1128/AEM.01396-13

Weese JS, Staempfli HR (2000) Diarrhea associated with enterotoxigenic Clostridium perfringens in a red-footed tortoise (Geochelone carbonaria). J Zoo Wildl Med 31:265-266. https:// doi.org/10.1638/1042-7260(2000)031[0265:DAWECP]2.0.CO;2

Young LS, Yap LF, Murray PG (2016) Epstein-Barr virus: More than 50 years old and still providing surprises. Nat Rev Cancer 16:789-802. https://doi.org/10.1038/nrc.2016.92

Zaytsoff SJM, Uwiera RRE, Douglas Inglis G (2020) Physiological stress mediated by corticosterone administration alters intestinal bacterial communities and increases the relative abundance of clostridium perfringens in the small intestine of chickens. Microorganisms 8:1-16. https://doi.org/10.3390/microorganisms 8101518

Zentek J, Marquart B, Pietrzak T, Ballèvre O, Rochat F (2003) Dietary effects on bifidobacteria and Clostridium perfringens in the canine intestinal tract. J Anim Physiol Anim Nutr (berl) 87:397-407. https://doi.org/10.1046/j.0931-2439.2003.00451.x

Zhang Y, Hou Z, Ma J (2012) Hemorrhagic enterocolitis and death in two felines (Panthera tigris altaica and Panthera leo) associated with Clostridium perfringens type A. J Zoo Wildl Med 43:394-396. https://doi.org/10.1638/2010-0197.1 